\title{
Quality Management in Slovene Public Administration: Opportunities for Learning from Experience
}

\section{Gordana Žurga*}

\author{
UDK $\quad 35.071 .5: 659.23(497.5)$ \\ 35.072.2:659.23(497.5) \\ Review scientific paper / pregledni znanstveni rad \\ Received/primljeno: 8. 1.2016. \\ Accepted / prihvaćeno: 16. 12. 2016.
}

Public administrations in practically all countries face challenges with respect to the efficiency and quality of their services. In their endeavours for better performance, they progressively implement general public management principles and quality management. Countries exercise different approaches which have a common aim: to build the institutional and administrative capacity to adequately support their political management and national economies. The paper will present the broader context of how countries could or should manage their public administrations to strengthen their administrative capacity for quality management and achieve sustainable public administration. Secondly, the paper will present the results of a comparative analysis of quality management in EU member states and the trends observed, and, thirdly, the case of

* Gordana, Žurga, PhD, Associate Professor at the Faculty of Organisation Studies in Novo Mesto, Slovenia (izvanredna profesorica Fakulteta organizacijskih studija u Novom Mestu, e-mail: gordana.zurga@siol.net). 
Slovenia will be used to illustrate the approach to quality management in public administration, together with future development goals.

Keywords: sustainable public administration, quality management, good practice, learning, CAF, Slovenia

\section{Introduction}

Contemporary challenges and approaches to quality in public administration are still very much influenced by the latest economic crisis, not only with respect to financing but also regarding the tasks and roles of states in the further development of their economies and society. While the first reaction of many countries affected by the economic crisis was to cut the expenses for their public administrations (Pollitt, 2009; Parrado \& Löffler, 2009), the approaches now are more directed at centralised priority setting by way of supporting the most effective government programmes, while cutting the non-effective programmes. More long-term measures and reforms are being explored and exercised to ensure sustainable public administration that would contribute to a sustainable national economy and the prosperity of society as a whole. Nevertheless, besides substantial changes in the availability of resources, countries also face changed demands for public services due to significant changes in society and in the established patterns of life (Žurga, 2009).

There are several demands and changed circumstances facing public administrations: social problems and social exclusion due to financial and economic crises, a low level of trust of politicians and public institutions, demographic changes, the rapid development of information and communication technologies, and the development of a differentiated civil society with new information and communication needs, which demands to be included in active policy formulation and decision-making processes. The key words are sustainable development, sustainable quality, and sustainable public administrations.

In the paper, special attention is given to quality management as a means of strengthening the administrative capacity in order to improve the effectiveness and efficiency of the government and its apparatus.

The main research question is how to ensure the institutional and adminis일 trative capacity to adequately support the political management of a state 
and its national economy. Special attention is dedicated to the area of quality management $(\mathrm{QM})$ in this respect: what trends public administrations follow across the European Union (EU), and how they can be considered at the national level. The case of Slovenia will be used for illustration purposes, and opportunities to learn from experience will be indicated.

The research methodology used is a combination of explorative and case study approaches. Basically, it consists of (1) an interpretation of the results of a comparative analysis of quality management in EU member states, conducted by the author in 2008; (2) a description of the sustainable public administration model, developed by the author in 2011; and (3) a case study - an illustration of the opportunities to learn from experience which support the sustainable public administration model with respect to administrative capacity.

Comprehensive development in the field of quality management in public administrations has been achieved in the last several decades. Establishing business excellence was defined as one of the four new public management models (Ferlie et al., 1996), and has been substantially developed since then. Different aspects of quality management in public administrations were explored: those oriented towards public administration customers (Löffler \& Vintar, 2004), usage of quality management tools in public administrations (Engl, 2003; Thijs \& Staes, 2005; Žurga, 2008a), ethics and integrity (Demmke, 2004; Krekel, 2005), and comparing developments at the national level (Bossaert \& Demmke, 2003; Žurga, 2008a). Alongside the development of quality management as a discipline, customer demands and expectations have also developed and evolved into the right to good administration becoming increasingly considered as a basic human right (Kieres, 2003; Oosting, 2003), and having strong implications regarding public managers. They have to become aware of their responsibility for quality public services, a responsibility that will not only be declarative but also pecuniary in the future (Žurga, 2006).

Development of quality management in public administrations has also had strong support at the level of international organisations (OECD, World Bank, IMD, and others) and European integrations. Different kinds of research studies were conducted regarding the role of public administration in the context of economic growth and competitiveness. For example, a study in 2007 explored the links between public administration modernisation, efficiency of public spending, governance, and economic growth (St. Aubin, 2007). The study proved that some governance features are more important for growth: namely, law and order (including the judicial system and control of corruption) and regulation quality. 
In the late 1990s the European Public Administration Network (EUPAN) was established. Quality management in public administrations in the EU is a core area of the Innovative Public Services Group (IPSG) of the EUPAN and supports development and learning at the international, national, and organisational level. An important element in this respect is managing the change effectively. From a methodological viewpoint, significant development has been achieved with respect to quality management principles and instruments. Two of the most recognisable products of the IPSG are the CAF (Common Assessment Framework) and European quality conferences.

A comprehensive comparative analysis of quality management in public administrations in the EU, performed in 2008, confirmed that quality has become an indispensable part of national public administration development, and is incorporated in strategic and developmental documents and plans (Žurga, 2008a). Another EUPAN study explored the contribution of national public administrations to the realisation of the Lisbon Strategy (LS) goals and possible connections between the actions taken and results achieved (Žurga, 2008b). The PA areas and reform initiatives reported by the member states as relevant for supporting national performance were: a reduction of administrative burdens (RAB), better regulations (BR), regulatory impact reform (RIA), e-government, integrated back office functions, sharing resources, public administration reform (PAR), quality management $(\mathrm{QM})$, structures, $\mathrm{R} \& \mathrm{D}$, and innovation. Three main types of PA focus were identified in the sense of method of achievement: RAB $\&$ BR, e-government, and PAR/QM / specific sector/policy. Although the two 2008 studies were not interdependent, the results clearly showed that EU member states with a longer quality management tradition contributed the most advanced national cases with respect to realising the Lisbon Strategy goals (Žurga, 2011).

The study of the contribution of public administrations to the Lisbon Strategy was updated in 2010, after the crisis had begun. It showed that the attention of the member states' national action programmes was predominantly directed towards the following: improving the efficiency and productivity of PA; rationalising public expenditure and reducing time spent on administrative procedures in order to provide better service to citizens and enterprises; incorporating regulatory reform through regulatory impact assessment and better regulation; reducing the administrative burdens and procedures for enterprises and citizens in order to improve the work and business environment; strengthening competitiveness; implementing institutional changes to restructuring the public sector by 
reducing/merging the number of administrative units or levels, aimed at finding synergies and creating a new and more efficient structure by means of removing overlapping functions; boosting and enabling innovation as the primary support for increasing productivity across all economic sectors; enhancing transparency and accountability; making information available to the citizens in order to explain public actions; and submitting public performance to evaluation by interested actors (Hidalgo, 2010).

The question of how QM in PA and quality public administration can contribute to national competitiveness became a central research question, and at the same time a very practical question for all EU member states and relevant international organisations. It has to be emphasised that EU member states also seek to answer these kinds of challenges in the context of the Europe 2020 Strategy as a European strategy for smart, sustainable, and inclusive growth. The task of every member state is to incorporate all the EU umbrella objectives in its development plans and adopt the appropriate measures (Žurga, 2011).

In 2012, a comprehensive study was performed on behalf of the European Commission, entitled Excellence in Public Administration for Competitiveness in EU Member States. The study aimed to develop a framework that could be used to assess excellence in public administration - conceived as a well-functioning, efficient, and modern administration - with respect to competitiveness (Pitlik et al., 2012). According to the study, the tools that have the most notable impact on the relationship between competitiveness and public sector excellence are: (1) electronic government, (2) human resources management, (3) performance orientation, (4) service orientation, and (5) the institutional reorganisation of administration.

\section{In Search of Sustainable Public Administration}

However, quality management and balancing the work of organisations and institutions in public administration and the public sector alone is not enough; we need structural changes, something that requires new policies and new forms of public management. Here, governments can play a proactive role in recognising the turbulence in its early stages and in developing competency in supervising structural changes.

It is up to the state to ensure the continuous functioning of its institutions for their users - citizens and business entities - and to simultaneously plan and carry out structural changes in a way that will ensure the desired long- 
term effects. There are two basic types of changes in public management: incremental and structural.

Incremental changes are changes within the system, while structural changes are changes of the system. Incremental changes do not alter existing structures and they happen continuously within existing frameworks. These changes are a series of continuous and gradual steps to bring functioning into balance. Incremental changes are about constantly improving performance, which is implemented by organisations with established quality management systems on a daily basis.

On the other hand, structural changes are markers of something inconsistent, sudden, and unexpected, and bring about extensive reorganisation. Structural changes cannot be carried out in existing managerial frameworks because they include altering these same managerial frameworks. Structural changes are linked to a high level of risk-taking: because of a potentially inadequate structural change regarding a systemic problem that is being addressed, the risk of turbulence is high, as is the risk that the change will not be properly managed.

\subsection{Balancing the Performance}

The current economic situation in many countries still requires both types of changes, as well as systems, organisations, and individuals who are qualified to implement these. In reality, the capacity and competency for implementing structural changes is usually inadequate, and solving systemic problems in particular is usually put on hold until the very last minute. Incompetence in dealing with structural problems can only bring about additional negative effects. According to Metcalfe (2010), it is therefore absolutely necessary that, when dealing with turbulences, we create a model that would ensure a clear and accurate diagnosis of the problem and also give guidelines to establish and use the necessary competency for turbulence management. In this sense, Les Metcalfe connects the competency/capacity of the system and the basic principles of its use with the concept of an ultra-stable system as a model for adjustment and learning.

The concept of ultra-stability is understood as the capacity of an adaptive system to respond selectively, namely, with incremental adjustments, to permanent and small problems, and with reorganisation when it faces occasional but serious discontinuities.

That is why ultra-stable systems have two feedback loops: the first-order feedback loop ensures permanent adjustment within set frameworks and 
policies, and maintains stability around the existing balance. On the other hand, the second-order feedback loop works in a non-linear way, with gaps, and is a response to discontinuities and important structural changes. Its function is to lead and guide in order to search for new areas of stability. Ultra-stability ensures that a system remains permanently on a set course, while still allowing it to reorganise and innovate when entirely new problems require a change in course.

\subsection{The Sustainable Public Administration Model}

The framework for defining the sustainability of public administrations includes and requires a clear definition of the scope of their operations and a responsibility for the results, establishing a culture of innovation and continuous improvement, and establishing public administration organisations as learning organisations (Žurga, 2013). The right balance between changes at the system level and at the organisational level is to be defined - in this respect, innovation is seen as an important source for both types of changes. Not all innovation requires structural changes at the system level; it may require changes at the organisational level (breakthrough projects) or it may address fine-tuning in accordance with the incremental method.

Taking into consideration contemporary challenges that require not only new approaches and solutions in providing public services, but also highly productive and results-oriented functioning, the basic elements of sustainable public administration can be defined as innovation, continuous improvement at the organisational level, and structural changes at the system level.

Innovation in the sense of searching for and implementing new or significantly improved ways of providing public goods and services has to become a value, and the culture of innovation needs to be incorporated into the functioning of the public administration system at all levels. This consequently means that innovation is relevant to everyone, and the public administration system needs to become an environment that fosters innovation. It is important that this kind of system be institutionalised - innovation should not be understood as a disturbance but as s fundamental guideline.

Continuous improvement in PA organisations is considerably developed in EU member states. Although there are different traditions in this area, it can be claimed beyond any doubt that some QM tools, for instance, the 
Common Assessment Framework (CAF), customer satisfaction management or benchmarking, benchlearning, and the exchange of good practices are broadly utilised and deployed. However, additional mechanisms are still required to institutionalise continuous improvement as the customary and usual way of functioning in PA, rather than an exception. The basic principles in this respect are connected to PA organisations with high performance, which are well-led; strategic; accountable; oriented towards results, their customers, and the citizens; involve their employees and stakeholders; are innovative; constantly improve; effectively use information and knowledge; and act and develop as learning organisations. Responsibility for results is personalised at all levels, the organisation achieves its goals, and uses resources effectively.

Figure 1: Sustainable public administration model

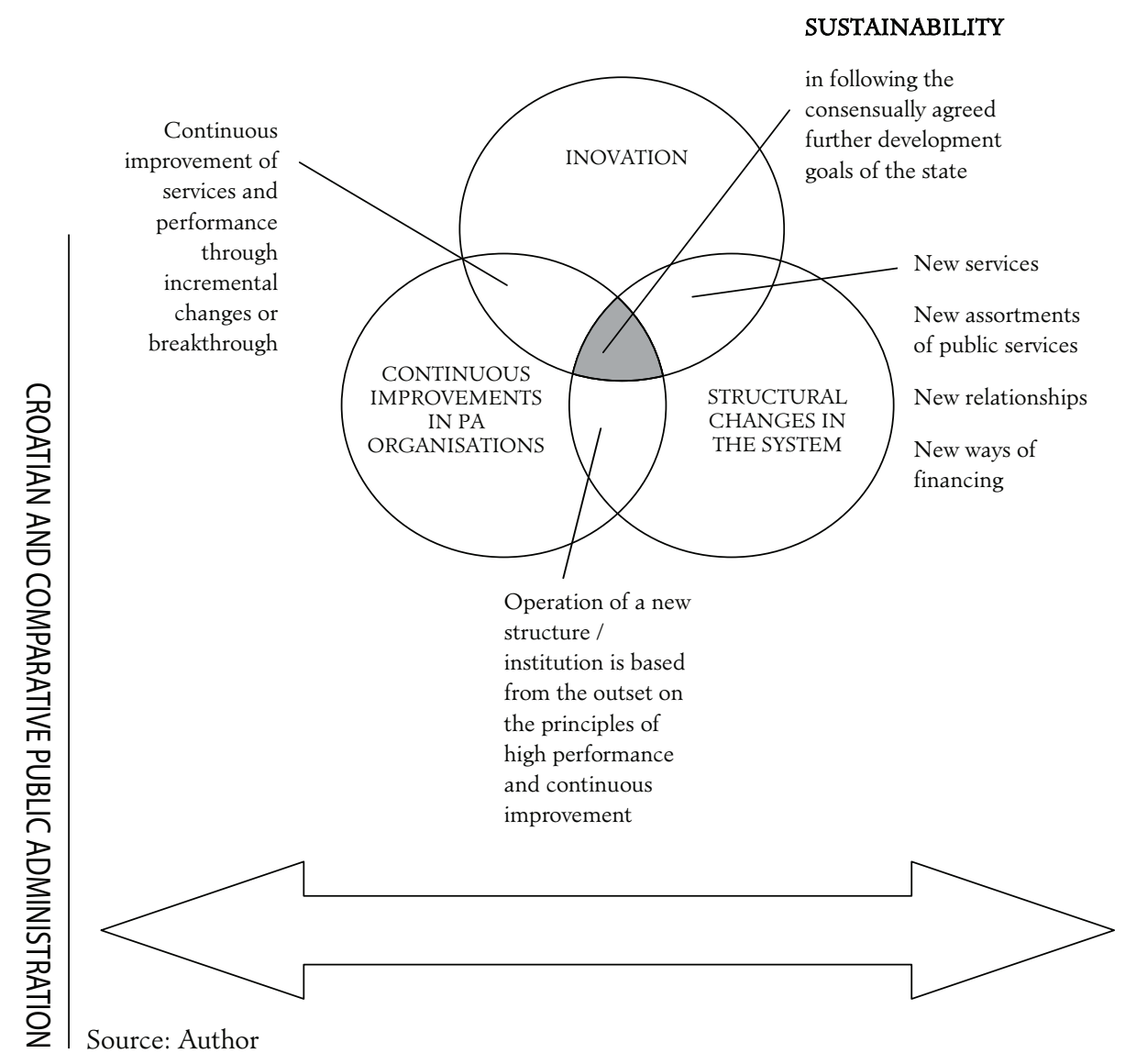


Structural changes in the system are defined as those kinds of changes in the PA system (and more broadly in the public sector) that are to be implemented when (new) problems require radically new solutions. A need for such changes is often derived from performance comparisons at the international level. This requires established mechanisms of constant checking of performance in an international context and a search for solutions by means of democratic dialogue between all relevant stakeholders, in which the political management of a state plays an important role.

All three elements of the model: innovation, continuous improvement in PA organisations, and structural changes in the system, are highly interrelated. The overlapping section between the three joint sections (indicated by dark grey shading in Figure 1) is defined as sustainability in following the consensually agreed further development goals of the state. It means that the sustainability of the public administration system is provided through clearly defined joint plans and rules of conduct, is constantly checked, and (corrective) actions and measures are adopted based on the results.

As a feedback loop, constant learning and organisational development is incorporated in the model in order to ensure constant improvement of specific elements and the system of public administration as a whole.

\subsection{Role and Responsibility of Public Managers}

However, it is a challenge for a public administration system to adapt effectively to changed demands, especially in conditions of low administrative capacity. In strengthening the administrative capacity of public administrations, divergent approaches are required to overcome the gap between increasing complexity and the ability of governments to control this complexity. Those that need to master the operations of public administration organisations are the heads and managers of these organisations. They must also have mechanisms in place to master changes and must continuously endeavour to increase the quality of their activities and services. They have to be aware that their responsibility of a public manager increases in modern times and that they require managerial knowledge (Žurga, 2009). In carrying out their activities, they have to be particularly aware that:

- The organisation they are heading is a business system, which requires agreements on activities and a suitable allocation of resources. They have to follow the purpose of their activities, including not only the provision of public services but also a responsibility for the further development of the system they are heading. They have to 
be proactive and serve as an example for their coworkers; only in this way will they be able to motivate them and create a suitable atmosphere, supportive of change implementation and continuous improvement. The most important characteristic of modern business systems is their dynamism.

- The organisational structure has to pursue the objectives of the organisation. If the goals change, the structure should adapt accordingly, otherwise it could impede the organisation in reaching new objectives and could turn into an obstacle. Objectives are not set for eternity, but change with time.

- Ways of measuring whether the organisation's objectives have been achieved have to be defined at the same time as they are set. The system of measuring carries significant value because it defines the importance of the objectives - they are important if they are measured. On the other hand, such a system has a powerful impact on the behaviour/activities of the employees or those included in the measurements; i.e., those who engage in the areas that are being measured and 'score points' as well as drop or do not carry out the activities that are not measured. The system of measurement can therefore help or hinder, and is undoubtedly linked to the system of values within an organisation. Measuring can influence what is measured and can transform that into a value, and as such is inseparably linked with the integrity of civil servants and the responsibility of public managers to guarantee that integrity.

- Ethical behaviour cannot be guaranteed solely through specific instruments or partial changes. Integrity and ethical behaviour also cannot be achieved overnight, but rather need to be created and encouraged. As values change with time, nurturing integrity has to be a permanent task. If public managers fail to recognise the importance of developing values, their clients will most likely lose trust in them.

- Finally, public managers have to be aware that they require adequate knowledge in order to perform their tasks. Knowledge necessary for solving new problems and challenges is becoming increasingly more interdisciplinary. Problems also differ from one another, requiring suitable methodological knowledge as the chosen method depends on the problem and not vice versa. An increasing number of issues cannot be solved with the level of knowledge available when they were created, which is why personal development of public administration managers is of key importance. 


\section{Approaches to Quality Management in Public Administrations - International Aspects}

In the year 2008, during its presidency of the Council of the EU, Slovenia conducted a comparative analysis of quality management in the public administrations of member states. The main findings of the analysis are:

(1) Quality is an indispensable part of national public administration development. The best way to ensure quality is to integrate it into all the strategic or reform documents of a country which relate to the further development of its public administration, as the "other side of the same coin".

(2) Long-standing quality management development in national public administrations expands the prospect (range) of some concepts, for instance, quality in the direction of business excellence, benchmarking in the direction of benchlearning, and customer orientation in the direction of good public management.

(3) An unequivocal international influence has been demonstrated: development, activities, and projects carried out within the European Public Administration Network and within the Innovative Public Services Group have had a powerful influence on quality management development in public administration at the national level.

(4) As a rule, the use of specific quality models and tools should not be obligatory or even required by law; the use of specific quality tools depends, to a certain extent, on the level of the maturity of a public administration organisation. The analysis showed that national governments clearly specified the quality tools in the public administration organisations they supported; in particular, they indicated the manner of their support (financial, material, professional, or any other).

(5) Various formal or informal means of networking, quality conferences, the dissemination of good practices, and similar activities have become increasingly important and have expanded.

Of course, there are differences among EU member states in approaches to quality management in their respective public administrations. The analysis has shown that the characteristics and results of quality management in public administrations are also dependent on the tradition countries have in this area.

Figure 2 illustrates the characteristics of quality management (QM) in the public administrations of the EU in relation to tradition, whereas Figure 3 shows when the member states started quality initiatives in their public administrations. 
Figure 2: Characteristics of quality management in public administrations in relation to tradition

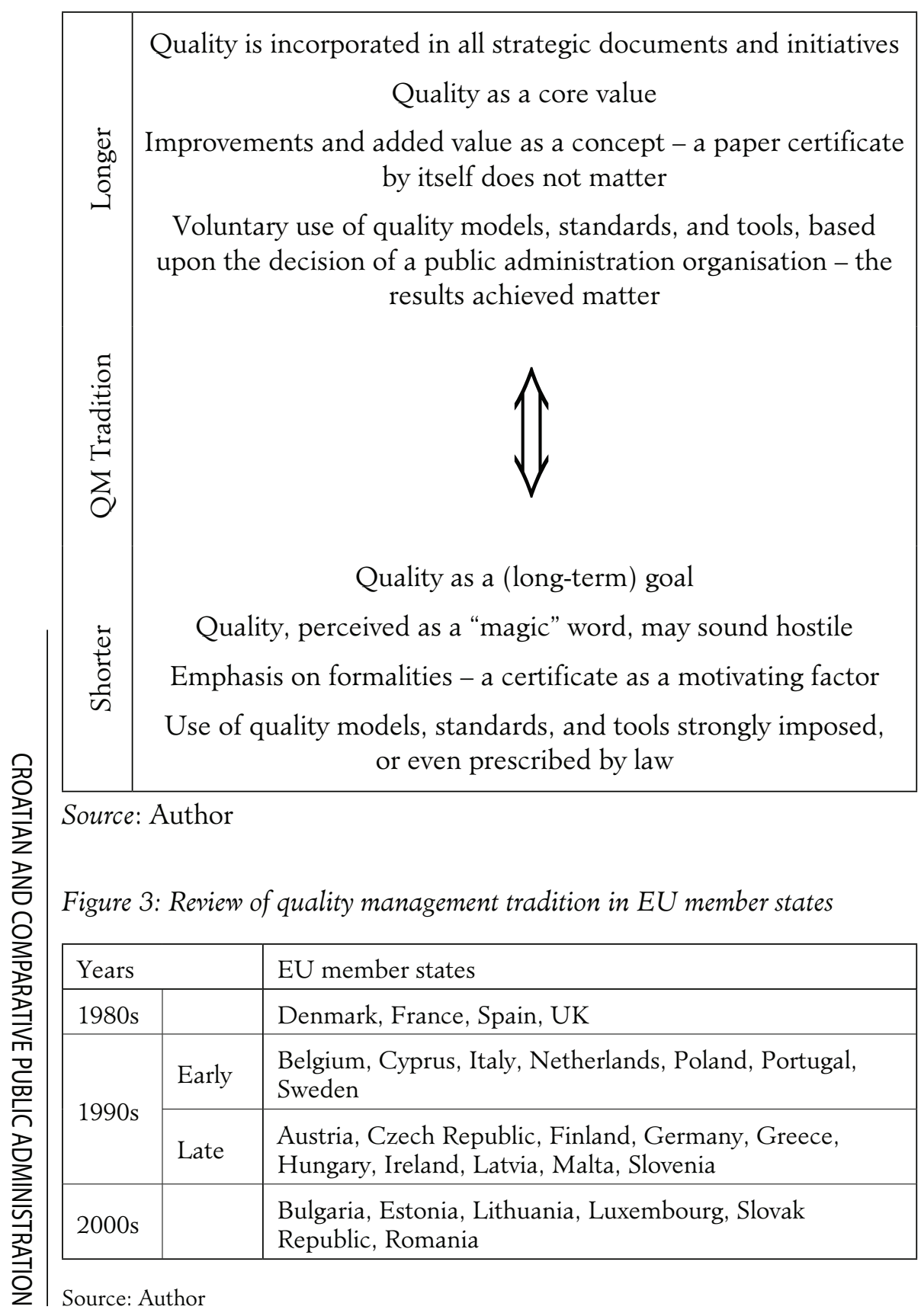


The research showed clearly that the development of quality management in European public administration is continuing in the direction of integrating quality into other developmental efforts and projects linked to public administrations in the various countries. It is also continuing to expand the range of existing concepts: from quality to business excellence, from benchmarking to benchlearning, from customer orientation (exclusively) from the position of consumption of administration services to good public management and public inclusion in decision-making.

\section{Quality Management in Slovene Public Administration}

\subsection{Characteristics of the Approach}

Activities in the area of quality and business excellence in Slovene public administration are characterised by a combination of "top-down" and "bottom-up" approaches.

The "top-down" approach is used in particular regarding the activities of the ministry responsible for public administration of the Government of the Republic of Slovenia. It is aimed at the (co)-preparation of different strategic and development documents relating to the quality of performance of the Slovene administration, development of joint basis, methodological tools and frameworks, as well as the institutionalisation of good practices and the introduction of quality standards into legislation.

The "bottom-up" approach denotes activities in the introduction of systems that will bring quality into specific bodies/organisations of public administration. It primarily relates to the introduction of quality management systems according to ISO 9000 standards, or according to the principles of business excellence, for example, CAF and EFQM. In the environments where greater managerial and organisational knowledge is present, other organisational models are used as well.

Public administration organisations generally follow the strategy of "incremental adjustment", which means that the changes in an organisation are introduced according to a step-by-step method. This strategy follows a rational approach and is based on continuity and a continuous adjustment of basic competences and processes of the organisation. It supports total quality management for the improvement of the organisation. The main characteristics and advantages of this strategy are: conformity of the organisational structure 
with its basic competences, adjustment of activities to the cultural norms of the organisation, implementation of corrections and adjustment of deviations with respect to the accepted standards, and an incessant search for opportunities to improve, be it within the organisation or outside of it.

It is important to note that intensive development in the area of quality in Slovene public administration has been most evident since the year 1999 when a Quality Committee was established at the ministry in charge of public administration. The main purpose of its activity was defined as an efficient, citizen-friendly, recognisable, and responsible public administration. Within this, the Quality Committee focused on the following goals: increasing effectiveness and efficiency, increasing the satisfaction of customers and employees, controlling costs, improving the transparency of operations, raising image and visibility, and gaining the ISO quality certificate for administrative units.

\subsection{Further Development of Quality Management}

In April 2015, the government of the Republic of Slovenia adopted the Public Administration Development Strategy 2015-2020. In July 2015, a two-year action plan was adopted for the implementation of this strategy in the period 2015-2016.

The vision of the government of the Republic of Slovenia as stated in the strategy, "is to organise a modern public administration which will observe the principles and values of: law and the rule of law; professionalism; participation; transparency, integrity and corruption prevention; responsiveness and user-orientation; consensus-orientation and integration; fairness and integration; innovation, success and efficient use of resources; and responsibility as the basis for measures and indicators of effectiveness, observation of public interest, satisfaction of citizens, companies, and other stakeholders with which it will achieve above-average results among EU Member States regarding high-quality service provision".

The key strategic goals are defined as:

- $\quad$ "responsive, effective and efficient operation of user-oriented public administration;

- efficient use of human, financial, spatial, environmental and energy resources;

- responsible, open and transparent operation of public administration; 
- zero tolerance to corruption, and enhancement of integrity;

- professionalism and development of professional competence and employee innovation;

- the system of flexible management of employees using mechanisms of responsibility, and the upgrading of the salary system with motivation mechanisms;

- the modernisation of administrative procedural law and the inspection system;

- improving quality systems, programme planning, operation review, measurable objectives and process indicators;

- improving legislation, reducing legislative burdens, assessing impacts, and including key stakeholders;

- efficient informatics, increased use of e-services, digitalisation and interoperability of information solutions."

With respect to the objective of introducing a comprehensive quality management system in public administration, the three sub-objectives are defined as:

(1) Strengthening the support and awareness of employees regarding the importance of quality as a value in public administration;

(2) Strengthening the quality management system development based on the CAF model and the exchange of good practices at all public administration levels:

- Setting a legal basis for the establishment of a quality management system and carrying out performance assessments of public administration organisations at the system level, based on the CAF model;

- Regular internal audits / self-assessments of the quality management system (CAF) in public administration at all levels and an improved review of quality management system implementation in state administration;

- External audits of the quality management system with an action plan for improvements - pilot implementation in 5 administrative bodies with 25 external assessors;

- Dissemination of knowledge and promotion through quality conferences, quality control, performance review, and responsibility with respect to resources;

(3) Strengthening the quality management system by the implementation of software to measure key goals and performance indicators. 
In the two-year action plan for the implementation of the 2015-2020 public administration development strategy, the time frame and indicators have been defined for individual areas until the end of 2016.

\section{Sharing Good Practice and Fostering Learning from Experience}

The sharing of good practices has been encouraged in Slovenian public administration since the early 2000s, when it was initiated by the activities of the Quality Committee. We would like to emphasise two main areas in this respect - quality conferences and CAF-related projects and activities. In both cases some direct results and implications are highlighted.

\subsection{Quality Conferences}

Between the years 2001 and 2010, the ministry in charge of public administration organised ten annual conferences on quality in Slovene public administration. At eight of these conferences, in the period $2002-2009$, good practice examples were chosen on the basis of a public call and upon predefined selection criteria. Twenty-five of these were awarded the 'Good Practice' prize. All were presented at the conferences and published in the conference proceedings. Besides the award-winning good practice cases, some other interesting good practice examples were published. In the table (see appendix), all the published good practice cases are listed together with the selection criteria (Žurga, 2010a).

The conference proceedings of all ten annual conferences on quality in Slovene public administration (also available in English from 2006) may be accessed on the website of the Ministry of Public Administration. ${ }^{1}$

It is important to note that starting in 2005 the quality conferences gradually became internationalised through the cooperation of distinguished speakers from the international arena and participants from abroad. Thus the 2009 conference hosted participants from seven countries in addition to Slovenia: Greece, Kazakhstan, Kyrgyzstan, Kosovo, Latvia, Poland, and Russia.

1 http://www.mju.gov.si/si/delovna_podrocja/razvoj_projektov_kakovost_javne_uprave_in_kohezijska_politika/konference_kakovosti/publikacije/ 
About 2,000 participants from Slovenia and the world attended the conferences, and around 110 speakers and lecturers presented.

Only the directly measured results are given above, but there are also numerous implications of these activities in Slovenia and in the European Union, because Slovenia is actively participating in furthering quality development at that level as well.

It is worth describing the added value of the quality conferences proceedings, which lies not only in disseminating good practices across Slovenia, but in disseminating examples of good national practice across the European Union and further afield. The purpose of publishing bilingual conference proceedings as of 2006 was to support the Slovenian presidency of the Council of the EU in 2008 and to spread word of how well the Slovenian administration was functioning, as well as to support the vision the Ministry of Public Administration defined at that time: to have one of the best public administrations in the European Union (Žurga, 2010b).

The idea of sharing cases of good practice in Slovene public administration was embraced in some sectors such as the police, the judiciary, and others. Despite the fact that the tradition of annual quality conferences was disrupted, the ministry in charge of public administration continues with the transfer and sharing of good practices in the form of different events, and publishes the relevant information on its website (as previously indicated).

\subsection{CAF-Related Projects and Activities}

In Slovenia, the CAF - Common Assessment Framework, is promoted and used as a quality management tool for fostering organisational, national, and international learning and development.

The systematic promotion and implementation of the CAF in Slovene public administration began as early as in 2002, first by translating the CAF into Slovene and establishing support activities at the ministry responsible for public administration. Afterwards, the CAF was included in strategic documents and initiatives at the state level. The CAF also remains a strategic direction for the future, and is included in the public administration development strategy 2015-2020.

Promotion of CAF and methodological support. Several activities are conducted by the ministry in charge of public administration, i. e., disseminating information on the CAF, CAF publications, CAF website, and 
methodological support in the form of self-assessment forms or providing information and measurements to support the 'Results' side of the CAF model.

Advisory meetings. Advisory meetings of the Ministry of Public Administration at public administration organisations, organised upon their request. At these meetings the approach to quality management in the organisation is discussed, as well as possible solutions regarding the organisation's 'starting' position - the CAF is a quality tool particularly strongly recommended for beginners.

CAF-Related Projects. Public administration organisations that have performed one or more CAF self-assessments gradually increase their level of maturity and would in time like to move forward in their efforts towards business excellence. Two such pilot projects are presented below: the result of the former was the establishment of the 'Public Sector' category in the national quality competition, and the results of the latter were included as a source in the further development of the CAF - CAF External Feedback procedure.

Participation in the Business Excellence Prize of the Republic of Slovenia (PR$S P \mathrm{O}^{2}$ ) competition. In 2004 a pilot project called PRSPO for public administration was carried out with the participation of the following administrative units: Grosuplje, Jesenice, Krško, Ljutomer, Maribor, Murska Sobota, Nova Gorica, Novo mesto, Slovenj Gradec, Slovenske Konjice, Šentjur pri Celju, Trebnje, and Tržič, and the Maribor Police Administration. At that time the pilot project was a joint venture between the Metrology Institute of the Republic of Slovenia (MIRS) and the Ministry of the Interior. The results achieved by the participating public administration organisations ( $301-350$ points) were up to 50 points higher than those achieved in comparable pilot projects (Kern Pipan \& Leon, 2005). Considering the organisations that participated in the pilot project, it can be concluded that the results achieved were not the result of a coincidence, but focused and consistent activity in this area in the years before: all the participating public administration organisations had already implemented quality management systems, mostly in conformity with the ISO 9000 standards or CAF. Since 2005, public administration organisations have been participating in the PRSPO in the public sector category.

A pilot project for assessing excellence in public administration based on the CAF was conducted in 2007. It was financed by the Ministry of Public

\footnotetext{
${ }^{2}$ PRSPO - Priznanje Republike Slovenije za poslovno odličnost.
} 
Administration, and implemented by the Faculty for Public Administration, in cooperation with the MIRS. The purpose of the project was to develop and establish a system of external assessment of quality in Slovene public administration organisations, based on the CAF model and the decree on administrative operations, in accordance with the standards of working with clients determined by public administration organisations.

The following public administration organisations took part in the pilot project: the Environmental Agency, Ljutomer Centre for Social Work, Novo mesto Police Administration, Market Inspectorate, Office of the Ombudsman, Metlika Administrative Unit, Velenje Administrative Unit, and the Employment Service of the Republic of Slovenia - Koper Regional Office.

Not only was the project important for the external verification of the organisations' results, but also for fostering learning and the transfer of good practice. The development of the assessment system is occurring in parallel with the development of a network of trained assessors, who will use the knowledge and experience acquired in this project in their own organisations as well as disseminate these in other environments.

As it was decided at the Ministry of Public Administration not to establish a system of recognition in Slovenia based on the CAF and parallel to EFQM recognition schemes, but to take part in the development of the CAF External Feedback, the results of the pilot project were used as important input regarding this further development of the CAF: the CAF External Feedback module.

Networking of CAF users. Alongside the promotion and usage of the CAF, the networking of Slovene public administration took place in the form of various, usually regionally-initiated, networks for the transfer of knowledge and experiences, for example:

- Territorial networking of various public administration entities which operate within a certain geographical area and share efforts towards better quality, efficiency, and better work results, some sources and/ or customers. Examples include an administrative centre, a joint committee for quality, local quality clusters, and so on.

- Undertaking of comparative learning (benchmarking and benchlearning) among the same type of public administration organisations - in the case of Slovenia, usually practically used by administrative units. This type of learning among the Slovene administrative units is widespread, because in addition to identifying the area where improvement is needed, it also encourages the exchange of experienc- 
es among colleagues (peer review) and raises the level of employee satisfaction. An example is a professional excursion among pairs of administrative units; employees from one administrative unit meet their peers at similar working places in another administrative unit.

- Comparisons and comparative analyses of public administration organisations (of the same type or different), undertaken on the basis of their own interests and needs. An example is a comparative survey of some performance indicators due to participation in the PRSPO competition.

- Exchange of knowledge and experiences among the same or different types of organisations by sharing experts in various fields. An example is the sharing/exchange of internal auditors.

It is important to emphasise that the networking described was established in accordance with the "bottom-up" approach, at the request of interested public administration organisations and upon their own initiative.

After over a decade of deliberate work, activities, and projects in the area of quality and business excellence in public administration it has been proved that the excellence of Slovenian public administration is being affirmed as a goal, and quality as one of its central values. In this context, the Common Assessment Framework is an important quality tool as it meets needs at both the national and the organisational level.

At the national level the CAF supports the implementation of TQM principles as well as the incremental method and the philosophy of continuous improvement of functioning and services.

At the organisational level the CAF supports the management of these organisations, basically due to the following reasons: it offers an organisational model for managing the organisation; enables organisational diagnostics and then a focus on improvement actions to the extent that suits the management in the given circumstances (duration, resources available); enables the monitoring and demonstration of the improvements; motivates employees; and, last but not least, the CAF builds a bridge towards more advanced and demanding quality management tools and approaches.

\section{Conclusion}

In Slovene public administration, quality management is recognised as a means for strengthening the administrative capacity for improving the effectiveness and efficiency of the government and its apparatus. 
Achieving sustainability in order to ensure the administrative capacity to effectively address current and future challenges requires an appropriate balance between structural and incremental changes in the system, fostering innovation and building a culture of innovation and change that is not only declarative but properly institutionalised as well.

Public administration organisations that act according to the principles of total quality management are adequately prepared to cope with changes of practically any kind. To note only a few examples: they practice customer/citizen orientation not only in the form of their products and services, but also by means of a different kind of citizen involvement in the consultation and decision-making processes, including the setting of strategic objectives and designing processes so that they do not cause administrative obstacles.

The development achieved thus far in the area of quality and business excellence proves that the excellence of Slovenian public administration is being affirmed as a goal, and quality as one of its central values. Quality is a value especially when it is incorporated in all the operations of an organisation and its employees who have internalised the principles of quality and excellence, and when the organisation itself is in a cycle of continuous learning and improvement. In Slovenia, considerable effort was invested in sharing good practices, networking, and comparative learning.

Based on the discussion and the sustainable public administration model three main conclusions are to be emphasised:

1) The more strategic and performance-oriented public administrations are, the more effectively they can support their political management in implementing the development goals of the state.

2) Achieving sustainability in order to ensure the administrative capacity to effectively address current and future challenges requires an appropriate balance between structural and incremental changes in the system, fostering innovation, and building a culture of innovation and change that is not only declarative but properly institutionalised as well.

3) Public administration organisations that act in accordance with the principles of total quality management are adequately prepared to cope with changes of practically any kind. To note only a few examples: they practice customer/citizen orientation not only in the form of their products and services, but also by way of a different kind of citizen involvement in consultation and decision-making processes, including the setting of strategic objectives and designing processes so that they do not cause administrative obstacles. 
However, it is a challenge for a public administration system to effectively adapt to changed demands, especially in conditions of low administrative capacity. It is therefore crucial for every state and its political management to increase government efficiency as seen in an international context to adequately support its economy as well as the citizens.

\section{References}

Bossaert, D., \& Demmke, C. (2003). Civil services in the accession states: New trends and the impact of the integration process. Maastricht, Netherlands: EIPA.

Demmke, C. (2004). Working towards common elements in the field of ethics and integrity. Maastricht, Netherlands: EIPA.

Engl, C. (2003). Quality management tools in CEE candidate countries. Maastricht, Netherlands: EIPA.

Ferlie, E., Ashburner, L., Fitzgerald, L., \& Pettigrew, A. (1996). The new public management in action. Oxford, UK: Oxford University Press.

Hidalgo, C. (2010). Evaluation of public administrations' added value to the Lisbon Strategy goals: Update 2010. Retrieved from: http://www.eupan.eu/files/repository/Final_Report_Evaluation_of_Public_Administrations2010.pdf

Kern Pipan, K., \& Leon, L. (2005). Izkušnje in perspektiva prvega pilotnega projekta Priznanja Republike Slovenije za poslovno odličnost (PRSPO) v javni upravi 2004 [Experiences and perspective of the first pilot project of Recognition of the Republic of Slovenia for Business Excellence (PRSPO) in public administration 2004]. Proceedings of the XII. Dnevi slovenske uprave: Uprava med politiko in stroko [XII Days of Slovene Administration 2005: The administration between politics and profession] conference (pp. 1-8). Ljubljana, Slovenia: Faculty of Administration.

Kieres, L. (2003). The constitutional basis for the right to good administration. Proceeding of the European Conference The right to good administration organised by the Council of Europe in collaboration with the Ministry of the Interior and of Public Administration of Poland and the Office of the Ombudsman in Poland (pp. 9-18). Warsaw, Poland: Council of Europe.

Krekel, P. (2005). Ethics and integrity in the public sector. New York, USA: EUPAN.

Löffler, E., \& Vintar, M. (2004). The current quality agenda of east and west European public services. In E. Löffler, \& M. Vintar (Eds.), Improving the quality of East and West European public services (pp. 3-19). Aldershot, UK: Ashgate

Metcalfe, L. (2010, April). The crisis: Challenges for public management. Paper presented at the $14^{\text {th }}$ Conference of the International Research Society for Public Management, Bern, Switzerland.

Parrado, S., \& Löffler, E. (2009). Towards sustainable public administration. Madrid, Spain: National Agency for the Evaluation of Public Policies and Quality of Services, Ministry of the Presidency. 
Oosting, M. (2003). The role of a modern administration in a state governed by the rule of law. Proceeding of the European Conference The right to good administration organised by the Council of Europe in collaboration with the Ministry of the Interior and of Public Administration of Poland and the Office of the Ombudsman in Poland (pp. 9-30). Warsaw, Poland: Council of Europe.

Pitlik, H., Hölzl, W., Brandtner, C., Heinemann, F., Misch, F., Yeter, M., \& Mertens, K. (2012). Study on 'Excellence in public administration for competitiveness in EU member states' prepared for the European Commission. Retrieved from http://www.eupan.eu/en/documents/show/\&tid=672

Pollitt, C. (2009). Public management reform during financial austerity. Stockholm, Sweden: Swedish Presidency of the European Union.

St. Aubin, M. (2007). Modernising public administration and economic growth. In G. Žurga (Ed.), Good practices in Slovene public administration 2007 (pp. 33-44). Zagreb, Croatia: Ministry of Public Administration.

Thijs, N., \& Staes, P. (2005). The common assessment framework in European public administrations: A state of affairs after five years. Eipascope, 3, 41-49.

Public administration development strategy 2015-2020 (2015). [Brochure]. Retrieved from http://www.mju.gov.si/fileadmin/mju.gov.si/pageuploads/JAVNA_UPRAVA/Kakovost/Strategija_razvoja_JU_2015-2020/Strategija_razvoja_ANG_final_web.pdf

Two-year action plan for the implementation of the 2015-2020 public administration development strategy for the period 2015-2016 (2015). Ministry of public administration, adopted by the Government of the Republic of Slovenia. Retrieved from http://www.mju.gov.si/en/areas_of_work/public_administration_2020/

Žurga, G. (2013). Contemporary challenges and approaches to quality in public administration: A European and national perspective. In D. Belošević (Ed.), Proceedings of the Kvaliteta - put izvrsnosti conference [Quality - A Pathway to Excellence] (pp. 473-482). Zagreb, Croatia: Hrvatsko društvo za kvalitetu.

Žurga, G. (2011a). Public administration's added value to the competitiveness of national economy. Zbornik radova Ekonomskog fakulteta u Rijeci, 29(1), 193223.

Žurga, G. (2011b). Sustaining quality of training for quality management in public administration. Proceedings of the IASIA annual conference: IASIA at 50Challenges and ways forward for public administration globally (pp.1-17). Rome, Italy: International Association of Schools and Institutes of Administration (IASIA) and the Roma Tre University.

Žurga, G. (2011c). Politični management: Od parcialnih interesov do odgovornega nosilca razvoja države [Political management - from partial interests to taking responsibility for the development of the state]. Javna uprava, 47(3/4), 5-30.

Žurga, G. (2010a). Organisacijsko učenje in izboljševanje kakovosti upravnega sistema prek prepoznavanja dobrih praks. In L. Bradač (Ed.), Dobre prakse v policiji (pp. 7-18). Ljubljana, Slovenia: Ministrstvo za notranje zadeve, Policija [Ministry of the Interior, Police]. 
Žurga, G. (2010b). Editorial. In G. Žurga (Ed.), Proceedings of the $10^{\text {th }}$ quality conference on public administration of theRrepublic of Slovenia 2010 (pp. 5-6). Ljubljana, Slovenia: Ministry of Public Administration.

Žurga, G. (2009). New trends in quality public service delivery. In K. Lisiecka \& T. Papaj (Eds.), Kierunki doskonalenia ustug świadczonych przez administracje publicizna: praca zbiorowa [Directions of improving the services provided by public administrations] (pp.11-18). Katowice, Poland: Ślaskie Centrum Społeczeństwa Informacyjnego: Akademia Ekonomiczna im. Karola Adamieckiego.

Žurga, G. (ed.) (2008a). Quality management in public administrations of the EU member states: Comparative analysis. Ljubljana, Sovenia: Ministry of Public Administration.

Žurga, G. (2008b). Quality management in the public administrations of the EU member states: Main findings and further development trends. In G. Žurga (Ed.), Proceedings of the Good practices in Slovene public administration 2008 conference (pp. 9-18). Ljubljana, Slovenia: Ministry of Public Administration.

Žurga, G. (2006). Quality and the right to good administration. In G. Žurga (Ed.), Proceedings of the Good practices in Slovene public administration 2006 conference (pp. 5-22). Ljubljana, Slovenia: Ministry of Public Administration. 
Žurga, G. (2016). Quality Management in Slovene Public Administration ...

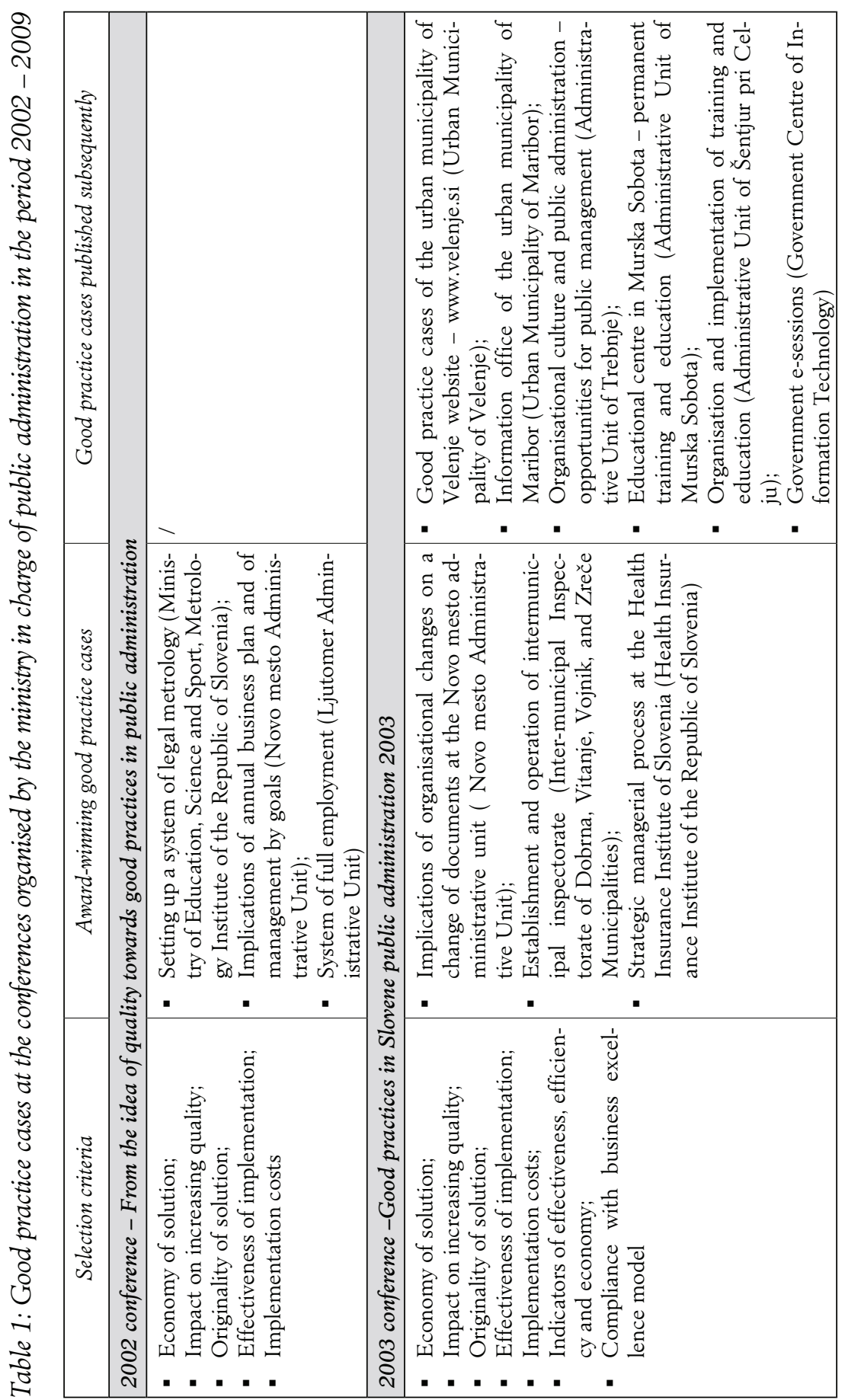

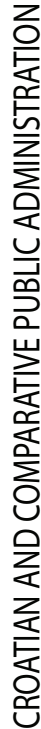


Žurga, G. (2016). Quality Management in Slovene Public Administration ... 842

HKJU-CCPA, 16(4), 817-846

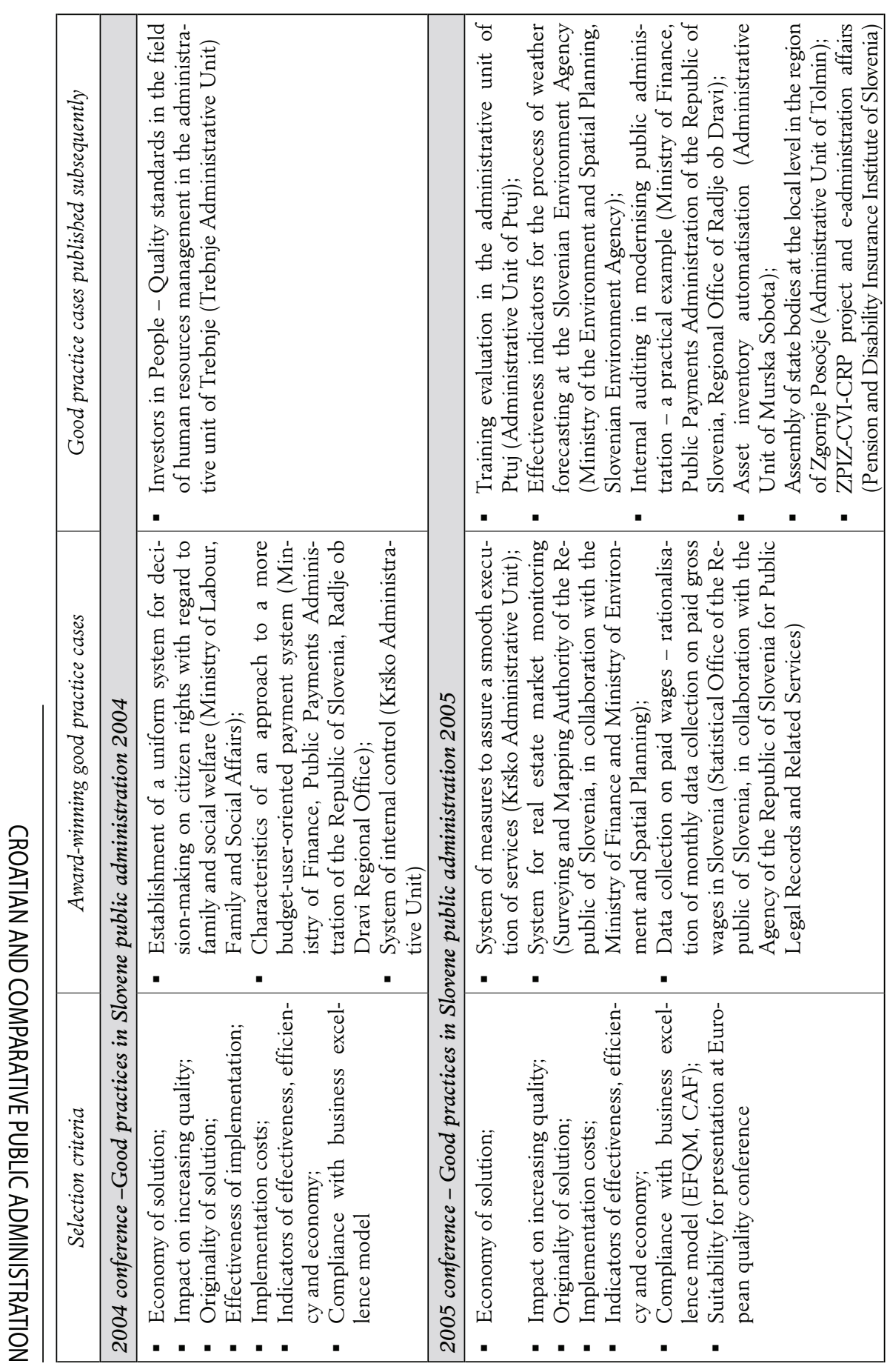


Žurga, G. (2016). Quality Management in Slovene Public Administration ...

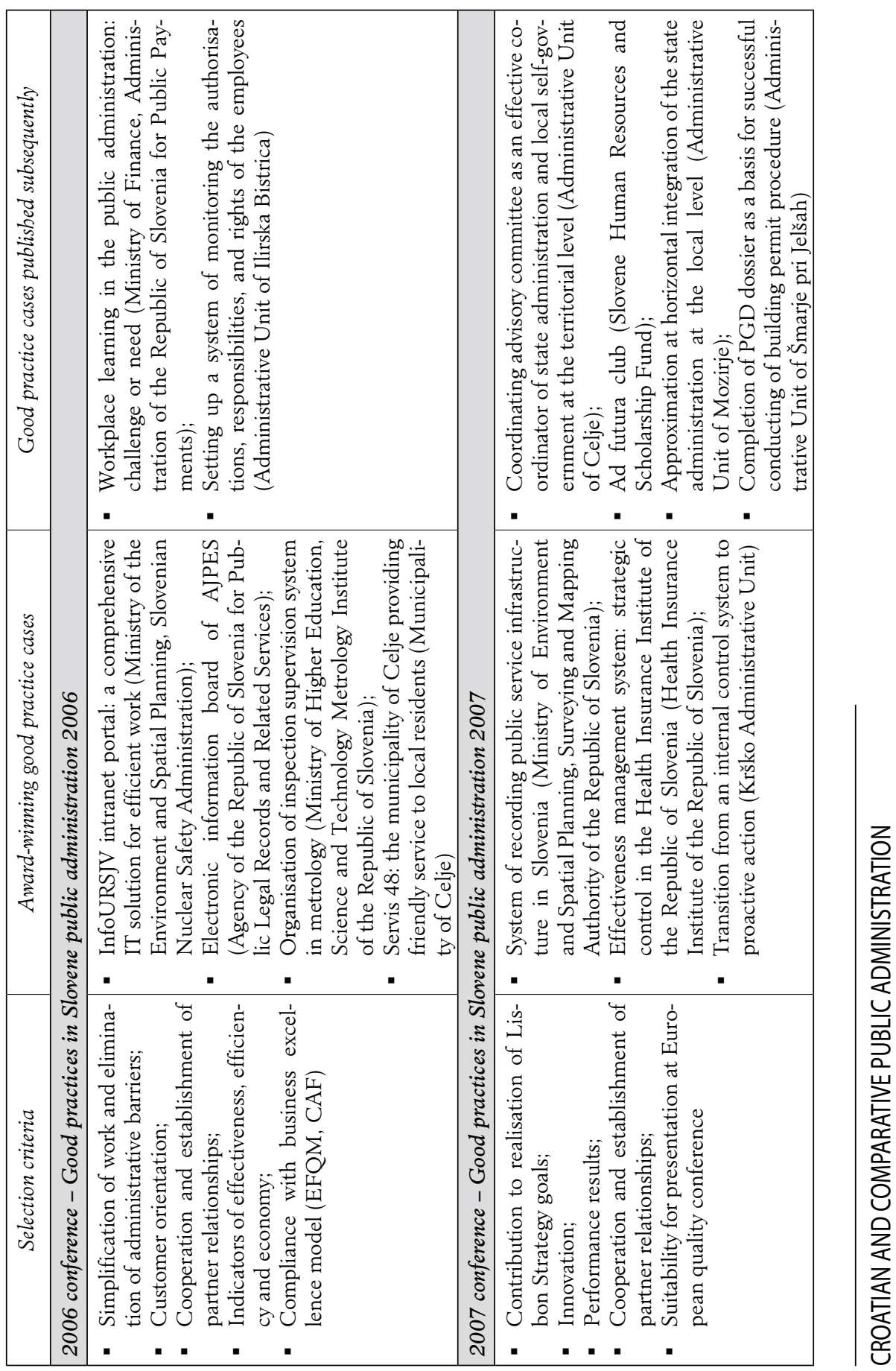


Žurga, G. (2016). Quality Management in Slovene Public Administration ... 844

HKJU-CCPA, 16(4), 817-846

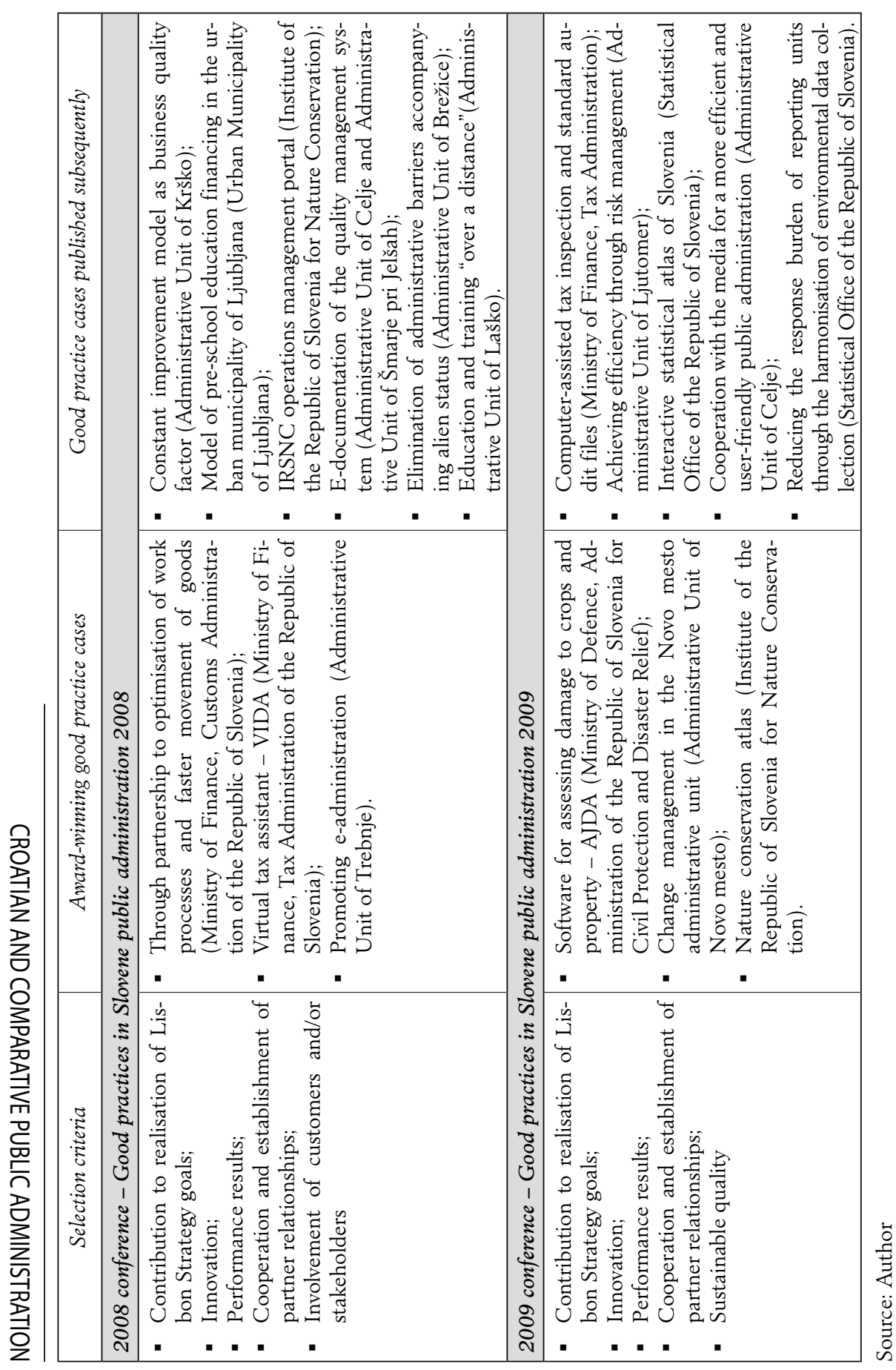




\title{
QUALITY MANAGEMENT IN SLOVENE PUBLIC ADMINISTRATION - OPPORTUNITIES FOR LEARNING FROM EXPERIENCE
}

\author{
Summary
}

Public administrations in practically all countries face challenges with respect to the efficiency and quality of their services. In their endeavours for better performance, they progressively implement general public management principles and quality management. Countries exercise different approaches which have a common aim: to build the institutional and administrative capacity to adequately support their political management and national economies. The paper will present the broader context of how countries could or should manage their public administrations to strengthen their administrative capacity for quality management and achieve a sustainable public administration. Secondly, the paper will present the results of a comparative analysis of quality management in EU member states and the trends observed, and, thirdly, the case of Slovenia will be used to illustrate the approach to quality management in public administration, together with future development goals.

Keywords: sustainable public administration, quality management, good practice, learning, CAF, Slovenia

\section{UPRAVLJANJE KVALITETOM U SLOVENSKOJ JAVNOJ UPRAVI -} PRILIKE ZA UČENJE IZ ISKUSTVA

\section{Sažetak}

Gotovo svugdje u svijetu javne se uprave suočavaju s izazovima u području učinkovitosti $i$ kvalitete usluga. Nastojeći unaprijediti rezultate postupno grade osnovne temelje javnog upravljanja kao i upravljanja kvalitetom. Različite države različito pristupaju ovom pitanju, no zajednički im je cilj izgradnja institucionalnih $i$ administrativnih kapaciteta koji će moći pružiti odgovarajuću podršku političkom upravljanju i nacionalnoj ekonomiji. U radu se predstavlja širi kontekst unutar kojeg pojedine države mogu ili trebaju na određeni način upravljati javnom upravom $i$ razviti administrativne kapacitete u svrbu upravljanja kvalitetom i postizanja održive javne uprave. Nadalje, predstavljaju se rezultati usporedne analize upravljanja kvalitetom u državama članicama 
EU-a i uočeni trendovi. Konačno, studija slovenskog slučaja pokazat će pristup upravljanju kvalitetom u slovenskoj javnoj upravi te planove za razvoj u budućnosti.

Ključne riječi: održiva javna uprava, upravljanje kvalitetom, dobra praksa, učenje, CAF, Slovenija 